\title{
Complete blood count in acute kidney injury prediction: a narrative review
}

\author{
Joana Gameiro* and José António Lopes
}

\begin{abstract}
Acute kidney injury (AKI) is a complex syndrome defined by a decrease in renal function. The incidence of AKI has raised in the past decades, and it is associated with negative impact in patient outcomes in the short and long term. Considering the impact of AKI on patient prognosis, research has focused on methods to assess patients at risk for developing AKI, diagnose subclinical AKI, and on prevention and treatment strategies, for which it is crucial an understanding of pathophysiology the of AKI. In this review, we discuss the use of easily available parameters found in a complete blood count to detect patients at risk for developing AKI, to provide an early diagnosis of AKI, and to predict associated patient outcomes.
\end{abstract}

Keywords: Acute kidney injury, Prognosis, Epidemiology, Biomarkers, Complete blood count, Ratio

\section{Background}

Acute kidney injury (AKI) is a complex syndrome defined as a rapid decrease in renal function, caused by numerous etiologies [1]. The incidence of AKI has raised in the past decades, occurring in up to $20 \%$ of hospitalized patients and the incidence is higher in critically ill patients $[2,3]$.

AKI has a negative impact in patient outcomes in the short and long term, increasing the risk of in-hospital mortality, longer hospital stays, cardiovascular events, progression to chronic kidney disease, and long-term mortality [4-6]. Overall, mortality rates associated with AKI have decreased reflecting the impact of the increased recognition of this diagnosis and improvements in patient care. Nevertheless, mortality rates are significant and increase with AKI severity, specifically in dialysis-requiring AKI [7, 8].

Given its impact on prognosis, it is important to recognize risk factors for its occurrence, such as advanced age, diabetes, hypertension, chronic kidney disease (CKD), cardiovascular disease (CVD), liver disease, lung disease, disease severity, sepsis, shock, nephrotoxicity, and surgery $[7-10]$ (Table 1$)$.

${ }^{*}$ Correspondence: joana.estrelagameiro@gmail.com

Division of Nephrology and Renal Transplantation, Department of Medicine, Centro Hospitalar Lisboa Norte, EPE, Av. Prof. Egas Moniz, 1649-035 Lisbon, Portugal
In the past decade, numerous studies have increased the understanding of the pathophysiology of AKI which led to the investigation of novel biomarkers. Nevertheless, the use of these biomarkers is limited in clinical practice.

The purpose of this review is to discuss the use of easily available parameters found in a complete blood count to detect patients at risk for developing AKI and to predict associated patient outcomes.

\section{AKI definition and biomarkers}

The definition of AKI has evolved significantly since 2004 when the Risk Injury Failure Loss of kidney function Endstage kidney disease (RIFLE) classification was first published [11]. The Acute Kidney Injury Network (AKIN) classification further revised these criteria, improving its diagnostic sensitivity and specificity [7]. The current definition of AKI was proposed by the Kidney Disease Improving Global Outcomes (KDIGO) work group in 2012 [12]. The KDIGO classification defines AKI as an increase in serum creatinine $(\mathrm{SCr})$ of at least $0.3 \mathrm{mg} / \mathrm{dl}$ within $48 \mathrm{~h}$, or an increase in $\mathrm{SCr}$ to more than 1.5 times baseline which is known or presumed to have occurred within the prior 7 days, or a urine output (UO) decrease to less than $0.5 \mathrm{ml} / \mathrm{kg} / \mathrm{h}$ for $6 \mathrm{~h}$. This classification also stratifies AKI in stages of severity which correlate with patient prognosis [12] (Table 2). 
Table 1 Risk factors for AKI

\begin{tabular}{l}
\hline AKI risk factors \\
\hline Advanced age \\
Diabetes \\
Hypertension \\
Chronic kidney disease \\
Cardiovascular disease \\
Liver disease \\
Lung disease \\
Disease severity \\
Shock \\
Sepsis \\
Nephrotoxins \\
Surgery
\end{tabular}

The definition of AKI depends on SCr and UO, which are imperfect markers of AKI [13-15]. SCr is an insensitive and delayed marker which is altered by factors affecting its production (age, gender, diet, and muscle mass), elimination (previous renal dysfunction), and secretion (medications). UO depends on patient's volemic and haemodynamic status and use of diuretics, is difficult to assess without a urinary catheter and its usefulness relies on an hourly assessment which is time-consuming [13-17].

Therefore, research has focused on the development of new biomarkers, including Cystatin- $\mathrm{C}$, neutrophil gelatinase-associated lipocalin (NGAL), $N$-acetyl-glucosaminidase (NAG), kidney injury molecule 1 (KIM-1), interleukin-6 (IL-6), interleukin-8 (IL-8), interleukin 18 (IL-18), liver-type fatty acid-binding protein (L-FABP), calprotectin, urine angiotensinogen (AGT), urine microRNAs, insulin-like growth factor-binding protein 7 (IGFBP7), and tissue inhibitor of metalloproteinases-2 (TIMP-2) [18-20]. These have been evaluated and validated in multiple settings, though their use in clinical practice is limited due to the associated costs and lack of evidence of better patient outcomes with their use in detecting AKI $[20,21]$.

A comprehensive understanding of the pathophysiology is critical to identify easily available predictors of AKI to prevent, diagnose, and treat this complication, ultimately improving patient outcomes.

\section{Pathophysiology of AKI}

AKI can be systematized clinically into three groups: prerenal, which accounts for up to $60 \%$ of cases and results from the functional adaptation to hypoperfusion of structurally normal kidneys; intrinsic renal results from structural damage to any component of the renal parenchyma and accounts for up to $40 \%$ of cases; and less frequently postrenal resulting from urinary tract obstruction [22-24].

Most cases are multifactorial and following the inciting event numerous pathophysiologic events occur, including hemodynamic instability, microcirculatory dysfunction, tubular cell injury, tubular obstruction, renal congestion,

Table 2 Risk, injury, failure, loss of kidney function, End-stage kidney disease (RIFLE) [11], Acute Kidney Injury Network (AKIN) [7], and Kidney Disease Improving Global Outcomes (KDIGO) [12] classifications

\begin{tabular}{|c|c|c|c|c|c|c|}
\hline \multirow[t]{2}{*}{ Class/stage } & \multicolumn{3}{|l|}{$\mathrm{SCr} / \mathrm{GFR}$} & \multicolumn{3}{|l|}{ UO } \\
\hline & RIFLE & AKIN & KDIGO & RIFLE & AKIN & KDIGO \\
\hline Risk/1 ${ }^{a}$ & $\begin{array}{c}\uparrow \mathrm{SCr} \times 1.5 \text { or } \downarrow \\
\text { GFR }>25 \%\end{array}$ & $\begin{array}{l}\uparrow \mathrm{SCr} \geq 26.5 \mu \mathrm{mol} / \mathrm{l} \\
(\geq 0.3 \mathrm{mg} / \mathrm{dl}) \text { or } \uparrow \\
\mathrm{SCr} \geq 150 \text { to } 200 \% \\
(1.5 \text { to } 2 \mathrm{X})\end{array}$ & $\begin{array}{l}\uparrow \mathrm{SCr} \geq 26.5 \mu \mathrm{mol} / \mathrm{l} \\
(\geq 0.3 \mathrm{mg} / \mathrm{dl}) \text { or } \uparrow \\
\mathrm{SCr} \geq 150 \text { to } 200 \% \\
(1.5 \text { to } 2 \mathrm{X})\end{array}$ & $<0.5 \mathrm{ml} / \mathrm{kg} / \mathrm{h}(>6 \mathrm{~h})$ & $<0.5 \mathrm{ml} / \mathrm{kg} / \mathrm{h}(>6 \mathrm{~h})$ & $<0.5 \mathrm{ml} / \mathrm{kg} / \mathrm{h}(>6 \mathrm{~h})$ \\
\hline Injury/2a & $\begin{array}{c}\uparrow \mathrm{SCr} \times 2 \text { or } \downarrow \\
\mathrm{GFR}>50 \%\end{array}$ & $\begin{array}{l}\uparrow \mathrm{SCr}>200 \text { to } 300 \% \\
(>2 \text { to } 3 \mathrm{X})\end{array}$ & $\begin{array}{l}\uparrow \mathrm{SCr}>200 \text { to } 300 \% \\
\quad(>2 \text { to } 3 X)\end{array}$ & $\begin{array}{l}<0.5 \mathrm{ml} / \mathrm{kg} / \mathrm{h} \\
\quad(>12 \mathrm{~h})\end{array}$ & $\begin{array}{l}<0.5 \mathrm{ml} / \mathrm{kg} / \mathrm{h} \\
\quad(>12 \mathrm{~h})\end{array}$ & $<0.5 \mathrm{ml} / \mathrm{kg} / \mathrm{h}(>12 \mathrm{~h})$ \\
\hline Failure $/ 3^{a}$ & $\begin{array}{l}\uparrow \mathrm{SCr} \times 3 \text { or } \downarrow \\
\mathrm{GFR}>75 \% \text { or } \\
\text { if baseline } \mathrm{SCr} \\
\geq 353.6 \mu \mathrm{mol} / / \\
(\geq 4 \mathrm{mg} / \mathrm{dl}) \uparrow \\
\mathrm{SCr}>44.2 \mu \mathrm{mol} / \mathrm{l} \\
(>0.5 \mathrm{mg} / \mathrm{dl})\end{array}$ & $\begin{array}{l}\uparrow \mathrm{SCr}>300 \%(>3 \mathrm{X}) \\
\text { or if baseline } \\
\mathrm{SCr} \geq 353.6 \mu \mathrm{mol} / \mathrm{l} \\
(\geq 4 \mathrm{mg} / \mathrm{dl}) \\
\uparrow \mathrm{SCr} \geq 44.2 \mu \mathrm{mol} / \mathrm{l} \\
(\geq 0.5 \mathrm{mg} / \mathrm{dl}) \text { or } \\
\text { initiation of renal } \\
\text { replacement } \\
\text { therapy }\end{array}$ & $\begin{array}{l}\uparrow \mathrm{SCr}>300 \% \\
(>3 \mathrm{X}) \text { or } \uparrow \mathrm{SCr} \text { to } \\
\geq 353.6 \mu \mathrm{mol} / \mathrm{l} \\
(\geq 4 \mathrm{mg} / \mathrm{dl}) \text { or } \\
\text { initiation of renal } \\
\text { replacement } \\
\text { therapy }\end{array}$ & $\begin{array}{l}<0.3 \mathrm{ml} / \mathrm{kg} / \mathrm{h} \\
\quad(>24 \mathrm{~h}) \text { or anuria } \\
(>12 \mathrm{~h})\end{array}$ & $\begin{array}{c}<0.3 \mathrm{ml} / \mathrm{kg} / \mathrm{h}(24 \mathrm{~h}) \\
\quad \text { or anuria }(12 \mathrm{~h})\end{array}$ & $\begin{array}{l}<0.3 \mathrm{ml} / \mathrm{kg} / \mathrm{h}(24 \mathrm{~h}) \\
\quad \text { or anuria }(12 \mathrm{~h})\end{array}$ \\
\hline
\end{tabular}

SCr serum creatinine, GFR glomerular filtration rate, UO urine output, RIFLE Risk, Injury, Failure, Loss of kidney function (dialysis dependence for at least 4 weeks), Endstage kidney disease (dialysis dependence for at least 3 months), AKIN Acute Kidney Injury Network, KDIGO Kidney Disease Improving Global Outcomes

a Risk class (RIFLE) corresponds to stage 1 (AKIN and KDIGO), Injury class (RIFLE) corresponds to stage 2 (AKIN and KDIGO), and Failure class (RIFLE) corresponds to stage 3 (AKIN and KDIGO) 
microvascular thrombi, endothelial dysfunction, and inflammation [23-26]. In recent years, the significant role of inflammation in the pathophysiology of AKI has been emphasized [27].

The immunopathogenesis of AKI involves a complex interaction of damage-associated molecular patterns, pathogen-associated molecular patterns, oxidative stress, hypoxia inducible factor, complement system, dendritic cells, neutrophils, lymphocytes, macrophages, platelets, and cytokines [28-31].

The initial damage to renal endothelial cells and proximal tubular epithelial cells produces cytokines resulting in infiltration of inflammatory cells, such as neutrophils, lymphocytes, and macrophages into the interstitium [24, 26-28]. These cells cause ischemic tubular epithelial and endothelial injury directly and indirectly by releasing oxygen radicals, prostaglandins, leukotrienes, and thromboxanes $[28,29]$. In addition, they produce pro and antiinflammatory cytokines that further increase or decrease inflammation in the kidney [28-30].

Local and systemic inflammation plays a significant part in the initiation and extension phases of AKI, in the multi-organ failure associated with AKI and also in the progression to chronic kidney disease which can result if these immune mechanisms persist $[28,30]$. The role of immune cells in the pathogenesis of AKI has been highlighted in several animal models, in which direct or indirect inhibition of immune cells attenuated renal injury [31-34].

Neutrophils are important components of innate immunity and respond rapidly to injury. Their contribution to AKI pathophysiology results from adherence to endothelium and release of cytokines, reactive oxygen species, and proteases $[30,35]$. Neutrophils regulate the acute phase of inflammation within the first $24 \mathrm{~h}$, which motivated their role as an early marker of the severity of AKI $[36,37]$.

Lymphocytes are the main components of adaptive immunity, which also play a significant role in the development and maintenance of AKI, directly by cellular damage and indirectly by producing pro-inflammatory cytokines [30-38]. Natural killer $\mathrm{T}$ cells are presumed to induce renal injury as they are directly cytotoxic and release pro-inflammatory cytokines and activate macrophages and neutrophils [39]. CD4+ T cells also contribute to the early phase of AKI. In later phases of AKI, infiltration of lymphocytes and macrophages predominates over neutrophils $[40,41]$. T cells appear to have a significant role in the repair phase of AKI and possibly contribute to the transition from AKI to chronic kidney disease. Regulatory $\mathrm{T}$ cells are significant in renoprotection and renal regeneration processes, through antiinflammatory cytokine release and promoting tubular proliferation [42]. Understanding these inflammatory processes may provide insight into future interventions to prevent or attenuate the consequences of AKI.

In addition, platelet and leucocyte interactions appear to be a critical step in inflammation, as both innate and adaptive immunity are mediated by the interaction of neutrophils, monocytes, lymphocytes, and platelets [4345]. Platelets adhere to the endothelial wall, modulate vascular permeability, recruit and activate leucocytes, and activate the complement system, thus contributing significantly to hemodynamic and inflammatory processes of AKI $[45,46]$.

Investigation has long focused on quantifying inflammation and determining its prognostic impact on AKI. With the limitations of the contemporary markers of AKI and the prognostic impact of this diagnosis, it was important to evaluate the role of parameters found in a complete blood count as early markers of AKI, disease severity and prognosis. In the following section, we present a review of the studies focused on the correlation of complete blood count results, AKI, and outcomes (Table 3).

\section{Complete blood count parameters and AKI Anemia}

Several studies have demonstrated the association of anemia, which is frequent in hospitalized patients and associated with worse outcomes, and AKI [47]. The contributory effects of anemia to AKI are likely multifactorial. The presence of lower hemoglobin predisposes patients to renal hypoxia and oxidative stress [48]. In addition, many anemic patients have subclinical renal disease which increases the susceptibility to renal insults [49].

Shema-Didi et al. reported an independent association between preexisting anemia and in-hospital AKI occurrence (OR $1.5(1.4-1.6), p<0.001)$ and that the severity of anemia correlated with AKI requiring renal replacement therapy (RRT) and mortality, in a retrospective study of 34,802 hospitalized patients [50].

In a retrospective cohort of 1248 post-acute myocardial infarction patients, admission hemoglobin levels and anemia were independently associated with AKI (OR $1.76(1.02-3.02), p=0.04)$ [51]. Abusaada et al. developed a score to predict AKI risk in patients with acute myocardial infarction based on clinical and laboratory data at admission, including anemia as an independent risk predictor along with decompensated heart failure, baseline renal function, diabetes, and tachycardia [52].

Han et al. identified a hemoglobin threshold for detecting an increased risk of AKI and an association of anemia and AKI and long-term mortality in a retrospective study of critically ill patients [53]. Interestingly, 
Table 3 Complete blood count parameters, AKI incidence, and outcomes

\begin{tabular}{|c|c|c|c|c|c|c|}
\hline Study & Design & Setting & $N$ & AKI definition & Incidence of AKI & Mortality \\
\hline \multicolumn{7}{|l|}{ Anemia } \\
\hline Shema-Didi et al. [50] & Retrospective & Hospitalized & 34,802 & RIFLE & $\begin{array}{l}\text { OR } 1.5(1.4-1.6) \\
p<0.001\end{array}$ & OR $6.3(4.6-8.5), p<0.001$ \\
\hline Karkouti et al. [56] & Retrospective & Post-cardiac surgery & 1444 & $\mathrm{SCr} \geq 50 \%$ & RR $2.6(2.0-3.3)$ & \\
\hline Shacham et al. [51] & Retrospective & $\begin{array}{l}\text { Post-acute myocardial } \\
\text { infarction }\end{array}$ & 1248 & AKIN & $\begin{array}{l}\text { OR } 1.76(1.02-3.02) \\
\quad p=0.04\end{array}$ & \\
\hline Han et al. [53] & Retrospective & Critically ill & 2145 & KDIGO & $\begin{array}{l}\text { OR } 1.76(1.349-2.291) \\
p<0.001\end{array}$ & $\begin{array}{l}\text { OR } 2.21(1.835-2.662) \\
\quad p<0.001\end{array}$ \\
\hline Arai et al. [59] & Prospective & $\begin{array}{l}\text { Post-transcatheter aor- } \\
\text { tic valve implantation }\end{array}$ & 3472 & $\begin{array}{l}\text { Valve Academic } \\
\text { Research Consortium } \\
\text { criteria }\end{array}$ & $\begin{array}{l}\text { OR } 1.82(1.45-2.29) \\
\quad p<0.01\end{array}$ & $\begin{array}{l}\mathrm{HR} 1.5(1.29-1.73) \\
\quad p<0.01\end{array}$ \\
\hline Powell-Tuck et al. [54] & Retrospective & Critically ill & 210 & AKIN & $\begin{array}{l}\text { OR } 0.82(0.65-1.03) \\
p=0.09\end{array}$ & \\
\hline Abusaada et al. [52] & Prospective & $\begin{array}{l}\text { Post-acute myocardial } \\
\text { infarction }\end{array}$ & 1107 & AKIN & $\begin{array}{l}\text { OR } 1.66(1.07-2.54) \\
p=0.022\end{array}$ & \\
\hline Choi et al. [61] & Retrospective & $\begin{array}{l}\text { Post-total hip replace- } \\
\text { ment arthroplasty }\end{array}$ & 2467 & AKIN & $\begin{array}{l}\text { OR } 2.036(1.369-3.028) \\
\quad p<0.001\end{array}$ & \\
\hline Malhotra et al. [55] & Prospective & Critically ill & 573 & KDIGO & $\begin{array}{l}\text { OR } 1.477(0.891-2.449) \\
\quad p=0.13\end{array}$ & \\
\hline Duque-Sosa et al. [57] & Retrospective & Post-cardiac surgery & 966 & KDIGO & $\begin{array}{l}\text { OR } 1.32(1.00-1.75) \\
p=0.05\end{array}$ & \\
\hline Gorla et al. [60] & Retrospective & $\begin{array}{l}\text { Post-thoracic endovas- } \\
\text { cular aortic repair }\end{array}$ & 144 & AKIN & $\begin{array}{l}\text { OR } 4.34(1.91-9.85) \\
\quad p<0.001\end{array}$ & $\begin{array}{l}\text { OR } 1.67(1.03-2.68) \\
P=0.036\end{array}$ \\
\hline Oprea et al. [58] & Retrospective & Post-cardiac surgery & 6130 & KDIGO & $\begin{array}{l}\mathrm{HR} 1.15(1.01 \text { to } 1.32) \\
\quad p=0.04\end{array}$ & $\begin{array}{l}\mathrm{HR} 1.50(1.25 \text { to } 1.79) \\
\quad p<0.001\end{array}$ \\
\hline Sreenivasan et al. [62] & Retrospective & $\begin{array}{l}\text { Post-coronary angiog- } \\
\text { raphy }\end{array}$ & 2055 & KDIGO & $\begin{array}{l}\text { OR } 5.3(3.8-7.3) \\
\quad p<0.001\end{array}$ & \\
\hline \multicolumn{7}{|l|}{ White blood cell count } \\
\hline Han et al. [63] & Prospective & Critically ill & 2079 & KDIGO & $\begin{array}{l}\text { Leucocytosis } \\
\text { OR } 2.05 \text { (1.39-3.031), } \\
p<0.001 \\
\text { Leucopenia } \\
\text { OR } 1.42(1.002-1.996) \\
\quad p=0.048\end{array}$ & $\begin{array}{l}\text { Leucocytosis } \\
\text { OR } 1.36(0.992-1.852), \\
\quad p=0.056 \\
\text { Leucopenia } \\
\text { OR } 1.40(1.025-1.912) \\
\quad p=0.035\end{array}$ \\
\hline \multicolumn{7}{|l|}{ Delta-neutrophil index } \\
\hline Kim et al. [64] & Retrospective & Sepsis-associated AKI & 346 & AKIN & OR 1.060, $p<0.001$ & $\mathrm{HR} 25.2, p<0.001$ \\
\hline \multicolumn{7}{|c|}{ Neutrophil-to-lymphocyte ratio } \\
\hline Kim et al. [65] & Retrospective & $\begin{array}{l}\text { Post-cardiovascular } \\
\text { surgery }\end{array}$ & 590 & KDIGO & $\begin{array}{l}N L R>4.5 \\
\text { OR } 3.26(1.51-7.06) \\
\quad p=0.003\end{array}$ & $\begin{array}{l}\text { HR } 1.02(1.01-1.04) \\
\quad p=0.006\end{array}$ \\
\hline Yilmaz et al. [69] & Retrospective & Septic patients & 118 & AKIN & $\begin{array}{l}\text { OR } 3.25(2.72-4.19) \\
\quad p<0.001\end{array}$ & \\
\hline Yuan et al. [68] & Retrospective & $\begin{array}{l}\text { Post-coronary angiog- } \\
\text { raphy }\end{array}$ & 1162 & $\mathrm{SCr} \geq 0.5$ within 3 days & $\begin{array}{l}\text { OR } 1.105(1.044-1.169) \\
p=0.001\end{array}$ & \\
\hline Alfeilat et al. [72] & Prospective & $\begin{array}{l}\text { Emergency depart- } \\
\text { ment }\end{array}$ & 294 & AKIN/KDIGO & $\begin{array}{l}N L R>5.5 \\
\text { OR } 6.4(2.7-16) \\
\quad p=0.031\end{array}$ & \\
\hline Gameiro et al. [73] & Retrospective & Cirrhotic patients & 186 & $\begin{array}{l}\mathrm{SCr} \geq 0.3 \text { in } 48 \mathrm{~h} \text { or } \\
\mathrm{SCr} \geq 50 \%\end{array}$ & $\begin{array}{l}\text { OR } 1.1(1.0-1.1) \\
p=0.028 ; N L R>6 \\
\text { OR } 2.4(1.0-5.8) \\
p=0.041\end{array}$ & \\
\hline Parlar et al. [66] & Retrospective & Post-cardiac surgery & 311 & KDIGO & $\begin{array}{l}\text { OR } 0.45(0.22-0.95) \\
p=0.04\end{array}$ & \\
\hline Bu et al. [70] & Retrospective & Septic patients & 132 & KDIGO & $\begin{array}{l}\text { OR } 1.047(1.005-1.091) \\
p=0.026\end{array}$ & \\
\hline Kim et al. [67] & Retrospective & Burn-injured patients & 473 & KDIGO & $\begin{array}{l}\text { OR } 1.094(1.064-1.125) \\
\quad p<0.001\end{array}$ & \\
\hline
\end{tabular}


Table 3 (continued)

\begin{tabular}{|c|c|c|c|c|c|c|}
\hline Study & Design & Setting & $N$ & AKI definition & Incidence of AKI & Mortality \\
\hline Younan et al. [74] & Retrospective & Critically ill trauma & 207 & KDIGO & $\begin{array}{l}\text { OR } 2.06(1.04-4.06) \\
p=0.04\end{array}$ & \\
\hline Fan et al. [75] & Retrospective & Critically ill AKI patients & 13,678 & KDIGO & & $\begin{array}{l}N L R>12.14 \\
H R 1.83(1.66-2.02) \\
\quad p<0.0001\end{array}$ \\
\hline \multicolumn{7}{|l|}{ Mean platelet volume } \\
\hline Han et al. [76] & Retrospective & $\begin{array}{l}\text { Critically ill AKI-CRRT } \\
\text { patients }\end{array}$ & 349 & Clinical evaluation & & $\begin{array}{l}\mathrm{HR} 1.08(1.010-1.155), \\
\quad p=0.023\end{array}$ \\
\hline \multicolumn{7}{|l|}{ Mean platelet ratio } \\
\hline Li et al. [78] & Retrospective & $\begin{array}{l}\text { Critically ill AKI-CRRT } \\
\text { patients }\end{array}$ & 223 & KDIGO & & $\begin{array}{c}\text { AUROC } 0.636(0.563- \\
0.708), p<0.001\end{array}$ \\
\hline \multicolumn{7}{|l|}{ Thrombocytopenia } \\
\hline Van Linden et al. [81] & Retrospective & $\begin{array}{l}\text { Post-trans-apical aortic } \\
\text { valve implantation }\end{array}$ & 270 & RIFLE & $\begin{array}{l}\text { OR } 4.4(1.6-12.2) \\
p=0.005\end{array}$ & \\
\hline Fan et al. [83] & Retrospective & Heat stroke patients & 176 & Clinical evaluation & $\begin{array}{l}\text { OR } 37.92(2.18-87.21) \\
\quad p<0.01\end{array}$ & \\
\hline Kertai et al. [82] & Retrospective & Post-cardiac surgery & 4217 & KDIGO & $\begin{array}{l}\text { OR } 1.14(1.09-1.20) \\
\quad p<0.0001\end{array}$ & $\begin{array}{l}\text { HR } 5.46(3.79-7.89) \\
\quad p<0.0001\end{array}$ \\
\hline Chao et al. [84] & Prospective & $\begin{array}{l}\text { Emergency depart- } \\
\text { ment, elderly }\end{array}$ & 136 & KDIGO & $\begin{array}{l}\text { HR } 1.85(1.05-3.28) \\
\quad p=0.03\end{array}$ & \\
\hline Wu et al. [85] & Retrospective & $\begin{array}{l}\text { Hemorrhagic shock } \\
\text { patients }\end{array}$ & 84 & KDIGO & $\begin{array}{l}\text { OR } 0.71(0.54-0.93) \\
\quad p<0.05\end{array}$ & $\begin{array}{l}\text { HR } 0.89(0.76-0.99) \\
\quad p<0.05\end{array}$ \\
\hline \multicolumn{7}{|c|}{ Neutrophil, lymphocyte and platelet ratio } \\
\hline Gameiro et al. [87] & Retrospective & $\begin{array}{l}\text { Post-abdominal } \\
\text { surgery }\end{array}$ & 450 & KDIGO & $\begin{array}{l}\text { OR } 1.05(1.00-1.10) \\
p=0.048\end{array}$ & \\
\hline Koo et al. [86] & Retrospective & Post-cardiac surgery & 1099 & KDIGO & $\begin{array}{l}\text { OR } 1.19(1.04-1.36) \\
p=0.0124 ; N L P R \geq 64 \\
\text { OR } 2.18(1.20-3.98) \\
p=0.011\end{array}$ & $\begin{array}{l}N L P R>3 \\
H R 3.54(2.00-6.28) \\
\quad p<0.001\end{array}$ \\
\hline \multicolumn{7}{|c|}{ Platelet-to-lymphocyte ratio } \\
\hline Hudzik et al. [89] & Retrospective & $\begin{array}{l}\text { Post-acute myocardial } \\
\text { infarction, diabetic } \\
\text { patients }\end{array}$ & 719 & $\mathrm{KDIGO}$ & $\begin{array}{l}\text { OR } 1.22(1.10-1.34) \\
p<0.0001\end{array}$ & \\
\hline Zheng et al. [91] & Retrospective & Critically ill AKI patients & 10,859 & KDIGO & & $\begin{array}{l}P L R<90 \\
H R 1.25(1.12-1.39) \\
\quad p<0.001 \\
P L R>311 \\
H R 1.19(1.08-1.31) \\
\quad p<0.001\end{array}$ \\
\hline Sun et al. [90] & Retrospective & $\begin{array}{l}\text { Post-acute myocardial } \\
\text { infarction, coronary } \\
\text { angiography }\end{array}$ & 5719 & $\begin{array}{l}\mathrm{SCr}>25 \% \text { or } \\
\quad>0.5 \mathrm{mg} / \mathrm{dl} \\
\text { within } 72 \mathrm{~h} \text { of contrast } \\
\text { exposure }\end{array}$ & $\begin{array}{l}\text { OR } 1.432(1.205-1.816,) \\
\quad p=0.031\end{array}$ & \\
\hline Parlar et al. [66] & Retrospective & Post-cardiac surgery & 311 & KDIGO & $\begin{array}{l}\text { OR } 1.06(1.01-1.10) \\
\quad p=0.01\end{array}$ & \\
\hline
\end{tabular}

AKIN Acute Kidney Injury Network; AKI Acute kidney injury; AUROC Area Under the Receiver Operating Characteristics; GFR glomerular filtration rate; HR Hazard Ratio; $K D I G O$ Kidney Disease Improving Global Outcomes; NLR neutrophil-to-lymphocyte ratio; NLPR neutrophil, lymphocyte, and platelet ratio; OR odds ratio; PLR plateletto-lymphocyte ratio; RIFLE Risk, Injury, Failure, Loss of kidney function, End-stage kidney disease; RR relative risk; SCr serum creatinine

a retrospective study by Powell-Tuck et al. of 210 critically ill patients with AKI stage I diagnosed by the AKI Network (AKIN) classification criteria reported that anemia did not increase the risk to progress to AKI stage III [54]. Malhotra et al. recently developed a risk prediction score in a prospective study of critically ill patients which included anemia as an independent predictor of AKI [OR 1.477 (0.891-2.449), $p=0.13$ ] [55].

In cardiac surgery patients, Karkouti et al. reported that the presence of preoperative anemia, intraoperative anemia, and red blood cell transfusion on the day of surgery had a 2.6-fold increase in the relative risk of AKI [56]. A Spanish multicenter retrospective cohort of 
cardiac surgery patients demonstrated that intraoperative anemia was independently associated with increased risk of AKI [OR 1.32 (1.00-1.75), $p=0.05]$ [57].

Oprea et al. also demonstrated the association of preoperative and postoperative anemia and AKI and AKI severity after coronary artery bypass grafting surgery (HR 1.15 (1.01-1.32), $p=0.04$ ). Furthermore, this study also demonstrated an association between anemia and long-term mortality (HR 1.50 (1.25 to 1.79 ), $p<0.001$ ) [58].

The presence of preoperative and postoperative anemia was also independently associated with AKI [OR 1.82 (1.45-2.29), $p<0.01$ ] and 1-year mortality [HR 1.5 (1.29$1.73), p<0.01]$ in a prospective study of patients undergoing transcatheter aortic valve implantation [59].

In patients undergoing thoracic endovascular aortic repair, Gorla et al. identified preoperative hemoglobin levels and postoperative hemoglobin levels decrease as risk factors for AKI and in-hospital mortality [60].

In a cohort of 2467 patients submitted to total hip replacement arthroplasty, postoperative anemia was associated with postoperative AKI [OR 2.036 (1.3693.028), $p<0.001$ ] [61]. Anemia was also an independent predictor of contrast-induced AKI in patients undergoing coronary angiography [62].

Therefore, anemia has long been a marker of poor patient prognosis and is important to take into account when evaluating a patient.

\section{White blood count}

The role of white blood cells (WBC) in the pathophysiology of AKI has been described above. Han et al. demonstrated a U-shaped relationship between WBC count and risk of AKI and mortality in a prospective cohort of critically ill patients [63]. They propose that the higher risk of AKI in leucocytosis could be related to neutrophilia and associated pro-inflammatory function, and the higher risk of AKI in leucopenia could be related to lymphopenia and monocytopenia which result in a lack of protective function [63].

Recently, Kim et al. reported the use of a calculated delta-neutrophil index (DNI), which reflects the fraction of immature WBC, to predict sepsis-associated AKI in the emergency department [64]. In their study, $\mathrm{DNI} \geq 14.0 \%$ was an independent predictor of severe AKI (OR 7.238, $p<0.001$ ) and severe AKI was an independent predictor of 30-day mortality (HR 25.2, $p<0.001$ ) in a cohort of septic patients [64].

\section{Neutrophil-to-lymphocyte ratio}

The neutrophil-lymphocyte ratio (NLR) is an easily calculated marker of systemic inflammation that has been recently demonstrated to effectively predict AKI in multiple settings.

In a retrospective cohort of 590 patients undergoing cardiovascular surgery, postoperative elevated NLR was significantly associated with an increased risk of postoperative AKI and mortality [65]. Parlar et al. also demonstrated that an increased NLR was associated with postoperative AKI in patients undergoing cardiovascular surgery with cardiopulmonary bypass [66]. An elevated preoperative NLR was also documented as a predictor of AKI in burn surgery patients, in whom a cut-off value of 11.7 was optimal for postoperative AKI prediction (OR 1.094 (1.064-1.125), $p<0.001)$ [67].

The NLR was associated with an increased risk of contrast-induced AKI, defined as an increase in $\mathrm{SCr}$ of $0.5 \mathrm{mg} / \mathrm{dl}$ within 3 days, in 1162 patients submitted to an emergency percutaneous coronary intervention (OR 1.105 (1.044-1.169), $p=0.001$ ) [68].

In patients with sepsis, NLR at admission has been demonstrated as an important predictor of AKI in two retrospective cohorts [69, 70]. Indeed, the systemic inflammation associated with septic-AKI is vital in the development of multi-organ failure [71]. In both studies, there was no correlation between NLR and mortality [71, 72].

Alfeilat et al. reported that a cut-off value of NLR $>5.5$ could be used to early detect AKI in a prospective study of 294 patients at emergency department admission $(\mathrm{NLR}>5.5$ OR 6.4 $(2.7-16), p=0.031)$ [72].

In a cohort of cirrhotic patients, we have developed a risk score for AKI combining renal, liver and inflammatory markers, which included the NLR [73]. In this retrospective study, a higher NLR was independently associated with AKI $(13.9 \pm 16.5$ vs $5.5 \pm 4.0, p<0.001$; unadjusted OR 1.2 (1.1-1.3), $p<0.001$; adjusted OR 1.1 (1.0-1.1), $p=0.028 ;$ NLR $>6$ OR 2.4 $(1.0-5.8), p=0.041)$ [73].

Furthermore, an increasing trajectory of NLR over the first $48 \mathrm{~h}$ of admission was associated with development of organ failure in critically ill male trauma patients (OR 2.06 (1.04-4.06), $p=0.04$ ) [74].

In a retrospective study of 13,678 critically ill AKI patients, Fan et al. demonstrated that an NLR higher than 12.14 was a predictor of all-cause mortality (HR 1.83 (1.66-2.02), $p<0.0001$ ) [75].

Although a standardized cut-off value for the NLR has not been defined, this easily calculated marker could be promising in the early diagnosis of AKI and as a prediction of worse outcomes.

\section{Platelet volume}

As described above, platelets have a significant role in the hemodynamic and inflammatory mechanisms of AKI. 
Thus, several studies have focused on platelet parameters as predictors of AKI and outcomes.

Han et al. demonstrated that mean platelet volume $(\mathrm{MPV}) \geq 10.2 \mathrm{fL}$ was a significant prognostic risk factor for 28-day mortality in a retrospective analysis of 349 AKI patients requiring continuous renal replacement therapy (CRRT) (HR 1.08 (1.010-1.155), $p=0.023)$ [76]. An increased MPV reflects increased platelet activity and turnover, which could reflect more severe inflammation and a risk factor for overall vascular mortality [77]. Li et al. developed the mean platelet volume/platelet count ratio (MPR) from a retrospective cohort of critically ill AKI patients CRRT [78]. In this study, MPR $>0.099$ was a significant predictor of mortality [AUROC 0.636 (0.5630.708), $p<0.001$ ] [78].

\section{Thrombocytopenia}

Thrombocytopenia has often been reported as an indicator of underlying disease severity and worse patient outcomes $[79,80]$.

Thrombocytopenia was an independent risk factor for postoperative AKI in patients undergoing minimally invasive transapical aortic valve implantation (OR 4.4 (1.6-12.2), $p=0.005$ ) [81]. There was also a significant association between postoperative thrombocytopenia and postoperative AKI (OR 1.14 (1.09-1.20), $p<0.0001$ ) and mortality (HR 5.46 (3.79-7.89), $p<0.0001$ ), in a retrospective study of patients undergoing after coronary artery bypass grafting surgery [82].

In a retrospective study of patients with heat stroke, thrombocytopenia at admission was also a predictor of AKI (OR $37.92(2.18-87.21), p<0.01)$ [83]. In addition, thrombocytopenia was associated with a higher risk of AKI in elderly patients in a prospective study of patients admitted to the emergency department [84].

In patients with hemorrhagic shock, thrombocytopenia in the first $48 \mathrm{~h}$ was associated with higher AKI and mortality risk [85]. Moreover, the severity of platelet count decrease had a significant correlation to the severity of AKI and mortality [85].

Hence, it is important to consider thrombocytopenia as an indicator of disease severity when assessing patients with AKI.

\section{Neutrophil, lymphocyte, and platelet ratio}

Koo et al. developed the neutrophil, lymphocyte, and platelet ratio (NLPR) in the setting of AKI after cardiovascular surgery [86]. The NLPR is calculated as follows:

(Neutrophil count $\times 100) /($ lymphocyte count $\times$ platelet count).

In their retrospective study of 1099 patients, higher perioperative NLPR were associated with postoperative AKI
$(\mathrm{NLPR} \geq 64$ OR $2.18(1.20-3.98), p=0.011)$ and 5-year mortality (NLPR $>3$ HR 3.54 (2.00-6.28), $p<0.001)$. This study demonstrated that adding platelet count to the NLR improved the predictive efficacy when compared to NLR or thrombocytopenia alone [86].

We have conducted a retrospective analysis in a cohort of patients undergoing major abdominal surgery and confirmed the predictive ability of NLPR in detecting AKI in this setting [OR 1.05 (1.00-1.10), $p=0.048]$; however, in our study, NLPR did not predict mortality [87].

Further studies should be conducted to validate the use of this ratio as a marker to detect risk of AKI and mortality.

\section{Platelet-to-lymphocyte ratio}

In recent publications, platelet-to-lymphocyte ratio (PLR) has been reported as new poor prognostic marker [88].

Hudzik et al. reported an association between higher PLR and risk of developing contrast-induced AKI in a retrospective analysis of diabetic patients with ST-elevation myocardial infarction (OR $1.22(1.10-1.34), p<0.0001)$ [89]. In this study, a PLR higher than 110 had a d $71 \%$ sensitivity and $63 \%$ specificity for predicting AKI [89]. The predictive ability of PLR was also demonstrated in a study by Sun et al. including also non-diabetic patients with STelevation myocardial infarction undergoing percutaneous coronary intervention (OR $1.432(1.205-1.816), p=0.031$ ) [90]. Sun et al. demonstrated that a PLR of 127.5 or higher had $76.8 \%$ sensitivity and $69.2 \%$ specificity to predict AKI [90].

In the setting of cardiac surgery, Parlar et al. also demonstrated that an elevated preoperative PLR was associated with early postoperative AKI [OR 1.06 (1.01-1.10), $p=0.01$ [ [66]. The cut-off value to predict AKI determined in this study was 136.85 , which demonstrated a sensitivity of $71.0 \%$ and specificity of $70.7 \%$ [66].

Interestingly, in a retrospective cohort of 10,859 critically ill AKI patients, Zheng et al. identified that both low and high PLRs were associated with an increased mortality risk [PLR $<90$ HR 1.25 (1.12-1.39), $p<0.001$; PLR $>311$ HR 1.19 (1.08-1.31), $p<0.001$ ] [91]. A lower PLR could result from the presence of thrombocytopenia which is also correlated with a worse prognosis in critically ill patients [91].

While promising, the PLR needs to analyze in further studies to confirm its validity as a diagnostic and prognostic marker.

\section{Strengths and limitations}

The complete blood count could be a useful tool to estimate the risk of developing AKI and mortality. Several parameters and indirect inflammation markers have been studied over the years with encouraging results.

Although some studies defined AKI with different criteria, the majority of studies used the KDIGO 
classification. The availability, low cost, and efficacy of these markers are an important advantage. The evidence is significant and the results have been replicated in large populations and many different settings, as depicted in Table 3.

Nonetheless, some important limitations have to be addressed. First, the majority of these studies are of a retrospective and single-center design which can compromise the results. Second, investigation has established a correlation between these parameters, AKI and mortality, determining the poor prognosis in these patients which could reflect disease severity and has not been able to prove causality between these. Finally, standardized cut-off parameters remain to be determined.

Therefore, before generalizing the use of complete blood count to predict AKI, further studies must be performed to confirm and validate these results, in preference with prospective design, larger populations, and longer follow-up.

\section{Conclusion}

AKI is a frequent complication in hospitalized patients with negative impact in the short and long term. It is crucial to identify easily available predictors of AKI to prevent, diagnose, and treat this complication, and to minimize the associated morbidity and mortality.

Research has developed new biomarkers, although their widespread use in clinical practice is still limited. The complete blood count could be useful to estimate the risk of developing AKI and mortality. Anemia, leucopenia, leucocytosis, and thrombocytopenia can estimate illness severity. NLR, NLPR, and PLR are simple and straightforward markers calculated from routine blood analysis, which have proven to be effective in predicting AKI and outcomes in multiple settings.

\section{Acknowledgements}

The authors have no acknowledgements.

\section{Authors' contributions}

The authors participated as follows: JG drafted the article; JAL revised the article. Both authors read and approved the final manuscript.

\section{Funding}

There was no funding for this study.

\section{Availability of data and materials}

Not applicable.

Ethics approval and consent to participate Not applicable.

\section{Consent for publication}

The authors give their consent for publication.

\section{Competing interests}

There are no competing interests. The results presented in this paper have not been published previously in whole or part.
Received: 24 April 2019 Accepted: 30 July 2019

Published online: 06 August 2019

\section{References}

1. Kellum JA, Prowle JR. Paradigms of acute kidney injury in the intensive care setting. Nat Rev Nephrol. 2018;14(4):217-30.

2. Hoste EA, Bagshaw SM, Bellomo R, Cely CM, Colman R, Cruz DN, et al. Epidemiology of acute kidney injury in critically ill patients: the multinational AKI-EPI study. Intensive Care Med. 2015:41:1411-23.

3. Bouchard J, Acharya A, Cerda J, Maccariello ER, Madarasu RC, Tolwani AJ, et al. A prospective international multicenter study of AKI in the intensive care unit. Clin J Am Soc Nephrol. 2015;10:1324-31.

4. Chertow G, Burdick E, Honour M, Bonventre J, Bates D. Acute kidney injury, mortality, length of stay, and costs in hospitalized patients. J Am Soc Nephrol. 2005;16(11):3365-70.

5. Hoste EAJ, Kellum JA, Selby NM, Zarbock A, Palevsky PM, Bagshaw SM, et al. Global epidemiology and outcomes of acute kidney injury. Nat Rev Nephrol. 2018;14(10):607-25.

6. Wald R, Quinn RR, Adhikari NK, Burns KE, Friedrich JO, Garg AX, et al. Risk of chronic dialysis and death following acute kidney injury. Am J Med. 2012;125:585-93.

7. Mehta RL, Kellum JA, Shah SV, Molitoris BA, Ronco C, Warnock DG, et al. Acute kidney injury network: report of an initiative to improve outcomes in acute kidney injury. Crit Care. 2007;11(2):R31.

8. Cruz DN, Ronco C. Acute kidney injury in the intensive care unit: current trends in incidence and outcome. Crit Care. 2007;11:149.

9. Ali T, Khan I, Simpson W, Prescott G, Townend J, Smith W, et al. Incidence and outcomes in acute kidney injury: a comprehensive population-based study. J Am Soc Nephrol. 2007:18:1292-8.

10. Lameire NH, Bagga A, Cruz D, De Maeseneer J, Endre Z, Kellum JA, et al. Acute kidney injury: an increasing global concern. Lancet. 2013;382(9887):170-9.

11. Bellomo R, Ronco C, Kellum JA, Mehta RL, Palevsky P, Acute Dialysis Quality Initiative workgroup. Acute renal failure-definition, outcome measures, animal models, fluid therapy and information technology needs: the Second International Consensus Conference of the Acute Dialysis Quality Initiative (ADQI) Group. Crit Care. 2004;8:R204-12.

12. Kdigo AK. KDIGO clinical practice guideline for acute kidney injury. Kidney Int Suppl. 2012;2:S1-138.

13. Thomas ME, Blaine C, Dawnay A, Devonald MA, Ftouh S, Laing C, et al. The definition of acute kidney injury and its use in practice. Kidney Int. 2015;87(1):62-73.

14. Ostermann M. Diagnosis of acute kidney injury: kidney disease improving global outcomes criteria and beyond. Curr Opin Crit Care. 2014;20(6):581-7.

15. Bellomo R, Ronco C, Mehta RL, Asfar P, Boisramé-Helms J, Darmon M, et al. Acute kidney injury in the ICU: from injury to recovery: reports from the 5th Paris International Conference. Ann Intensive Care. 2017;7(1):49.

16. Waikar SS, Betensky RA, Emerson SC, Bonventre JV. Imperfect gold standards for kidney injury biomarker evaluation. J Am Soc Nephrol. 2012;23:13-21.

17. Macedo E, Malhotra R, Claure-Del Granado R, Fedullo P, Mehta RL. Defining urine output criterion for acute kidney injury in critically ill patients. Nephrol Dial Transplant. 2011;26(2):509-15.

18. Lima C, Macedo E. Urinary biochemistry in the diagnosis of acute kidney injury. Dis Markers. 2018;2018:4907024.

19. Vanmassenhove J, Vanholder R, Nagler E, Van Biesen W. Urinary and serum biomarkers for the diagnosis of acute kidney injury: an in-depth review of the literature. Nephrol Dial Transplant. 2013;28(2):254-73.

20. Ostermann M, Joannidis M. Biomarkers for AKI improve clinical practice: no. Intensive Care Med. 2015;41(4):618-22.

21. Honore PM, Spapen HD. Oxidative stress markers and septic acute kidney injury: novel research avenue or road to nowhere? Ann Intensive Care. 2016;6(1):100

22. Ostermann M, Liu K. Pathophysiology of AKI. Best Pract Res Clin Anaesthesiol. 2017;31(3):305-14. 
23. Case J, Khan S, Khalid R, Khan A. Epidemiology of acute kidney injury in the intensive care unit. Crit Care Res Pract. 2013;2013:479730.

24. Akcay A, Nguyen Q, Edelstein CL. Mediators of inflammation in acute kidney injury. Mediators Inflamm. 2010;2009:137072.

25. Basile DP, Anderson MD, Sutton TA. Pathophysiology of acute kidney injury. Compr Physiol. 2012;2(2):1303-53.

26. Devarajan P. Update on mechanisms of ischemic acute kidney injury. J Am Soc Nephrol. 2006;17(6):1503-20.

27. Kinsey GR, Li L, Okusa MD. Inflammation in acute kidney injury. Nephron Exp Nephrol. 2008;109(4):e102-7.

28. Radi ZA. Immunopathogenesis of Acute Kidney Injury. Toxicol Pathol. 2018:46(8):930-43.

29. Lee DW, Faubel S, Edelstein CL. Cytokines in acute kidney injury (AKI). Clin Nephrol. 2011;76(3):165-73.

30. Jang HR, Rabb H. Immune cells in experimental acute kidney injury. Nat Rev Nephrol. 2015;11(2):88-101.

31. Hayama T, Hayama T, Funao K, Naganuma T, Kawahito Y, Sano H, et al. Benefical effect of neutrophil elastase inhibitor on renal warm ischemia reperfusion injury in the rat. Transplant Proc. 2006;38:2201-2.

32. Sakr M, Zetti G, McClain C, Gavaler J, Nalesnik M, Todo S, et al. The protective effect of FK506 pretreatment against renal ischemia/reperfusion injury in rats. Transplantation. 1992;53:987-91.

33. Jones EA, Shoskes DA. The effect of mycophenolate mofetil and polyphenolic bioflavonoids on renal ischemia reperfusion injury and repair. J Urol. 2000;163:999-1004.

34. Costa NA, Gut AL, Azevedo PS, Tanni SE, Cunha NB, Magalhães ES, et al. Erythrocyte superoxide dismutase as a biomarker of septic acute kidney injury. Ann Intensive Care. 2016;6(1):95.

35. Lee SA, Noel S, Sadasivam M, Hamad ARA, Rabb H. Role of immune cells in acute kidney injury and repair. Nephron. 2017;137(4):282-6.

36. Zuk A, Bonventre JV. Acute kidney injury. Annu Rev Med. 2016;67:293-307.

37. Friedewald JJ, Rabb H. Inflammatory cells in ischemic acute renal failure. Kidney Int. 2004;66:486-91.

38. Weller S, Varrier M, Ostermann M. Lymphocyte function in human acute kidney injury. Nephron. 2017;137(4):287-93.

39. Zhang ZX, Wang S, Huang X, Min WP, Sun H, Liu W, et al. NK cells induce apoptosis in tubular epithelial cells and contribute to renal ischemia-reperfusion injury. J Immunol. 2008;181:7489-98.

40. Bonventre JV. Pathophysiology of acute kidney injury: roles of potential inhibitors of inflammation. Contrib Nephrol. 2007;156:39-46.

41. Burne MJ, Daniels F, Ghandour A, Mauiyyedi S, Colvin RB, O'Donnell MP, et al. Identification of the CD4(+) T cell as a major pathogenic factor in ischemic acute renal failure. J Clin Invest. 2001;108:1283-90.

42. Kinsey GR, Sharma R, Huang L, Li L, Vergis AL, Ye H, et al. Regulatory T cells suppress innate immunity in kidney ischemia-reperfusion injury. J Am Soc Nephrol. 2009:20:1744-53.

43. Ioannou A, Kannan L, Tsokos GC. Platelets, complement and tissue inflammation. Autoimmunity. 2013;46(1):1-5.

44. Engelmann B, Massberg S. Thrombosis as an intravascular effector of innate immunity. Nat Rev Immunol. 2013;13(1):34-45.

45. Li Z, Yang F, Dunn S, Gross AK, Smyth SS. Platelets as immune mediators: their role in host defense responses and sepsis. Thromb Res. 2011;127:184-8.

46. Jansen M, Florquin S, Roelofs J. The role of platelets in acute kidney injury. Nat Rev Nephrol. 2018;14(7):457-71.

47. du Cheyron D, Parienti JJ, Fekih-Hassen M, Daubin C, Charbonneau P. Impact of anemia on outcome in critically ill patients with severe acute renal failure. Intensive Care Med. 2005;31:1529-36.

48. Darby PJ, Kim N, Hare GM, Tsui A, Wang Z, Harrington A, et al. Anemia increases the risk of renal cortical and medullary hypoxia during cardiopulmonary bypass. Perfusion. 2013;28(6):504-11.

49. Estrella MM, Astor BC, Kottgen A, Selvin E, Coresh J, Parekh RS. Prevalence of kidney disease in anaemia differs by GFR estimating method: the Third National Health and Nutrition Examination Survey (1988-94). Nephrol Dial Transplant. 2010;25:2542-8.

50. Shema-Didi L, Ore L, Geron R, Kristal B. Is anemia at hospital admission associated with in-hospital acute kidney injury occurrence? Nephron Clin Pract. 2010;115(2):c168-76.

51. Shacham Y, Gal-Oz A, Leshem-Rubinow E, Arbel Y, Flint N, Keren G, Roth A et al. Association of admission hemoglobin levels and acute kidney injury among myocardial infarction patients treated with primary percutaneous intervention. Can J Cardiol. 2015;31(1):50-5.

52. Abusaada K, Yuan C, Sabzwari R, Butt K, Maqsood A. Development of a novel score to predict the risk of acute kidney injury in patient with acute myocardial infarction. J Nephrol. 2017;30(3):419-25.

53. Han SS, Baek SH, Ahn SY, Chin HJ, Na KY, Chae DW, et al. Anemia is a risk factor for acute kidney injury and long-term mortality in critically ill patients. Tohoku J Exp Med. 2015;237(4):287-95.

54. Powell-Tuck J, Crichton S, Raimundo M, Camporota L, Wyncoll D, Ostermann M. Anaemia is not a risk factor for progression of acute kidney injury: a retrospective analysis. Crit Care. 2016;8(20):52.

55. Malhotra R, Kashani KB, Macedo E, Kim J, Bouchard J, Wynn S, et al. A risk prediction score for acute kidney injury in the intensive care unit. Nephrol Dial Transplant. 2017;32(5):814-22

56. Karkouti K, Grocott HP, Hall R, Jessen ME, Kruger C, Lerner AB, et al. Interrelationship of preoperative anemia, intraoperative anemia, and red blood cell transfusion as potentially modifiable risk factors for acute kidney injury in cardiac surgery: a historical multicentre cohort study. Can J Anaesth. 2015;62(4):377-84.

57. Duque-Sosa P, Martínez-Urbistondo D, Echarri G, Callejas R, Iribarren MJ, Rábago G, et al. Perioperative hemoglobin area under the curve is an independent predictor of renal failure after cardiac surgery. Results from a Spanish multicenter retrospective cohort study. PLoS ONE. 2017;12(2):e0172021.

58. Oprea AD, Del Rio JM, Cooter M, Green CL, Karhausen JA, Nailer P, et al. Pre- and postoperative anemia, acute kidney injury, and mortality after coronary artery bypass grafting surgery: a retrospective observational study. Can J Anaesth. 2018;65(1):46-59.

59. Arai T, Morice MC, O'Connor SA, Yamamoto $M$, Eltchaninoff $H$, Leguerrier A, FRANCE 2 Registry Investigators, et al. Impact of pre- and postprocedural anemia on the incidence of acute kidney injury and 1-year mortality in patients undergoing transcatheter aortic valve implantation (from the French Aortic National CoreValve and Edwards 2 [FRANCE 2] Registry). Catheter Cardiovasc Interv. 2015;85(7):1231-9.

60. Gorla R, Tsagakis K, Horacek M, Mahabadi AA, Kahlert P, Jakob H, et al. Impact of preoperative anemia and postoperative hemoglobin drop on the incidence of acute kidney injury and in-hospital mortality in patients with type B acute aortic syndromes undergoing thoracic endovascular aortic repair. Vasc Endovasc Surg. 2017;51(3):131-8.

61. Choi YJ, Kim SO, Sim JH, Hahm KD. Postoperative anemia is associated with acute kidney injury in patients undergoing total hip replacement arthroplasty: a retrospective study. Anesth Analg. 2016:122(6):1923-8.

62. Sreenivasan J, Zhuo M, Khan MS, Li H, Fugar S, Desai P, et al. Anemia (hemoglobin $\leq 13 \mathrm{~g} / \mathrm{dL}$ ) as a risk factor for contrast-induced acute kidney injury following coronary angiography. Am J Cardiol. 2018;122(6):961-5.

63. Han SS, Ahn SY, Ryu J, Baek SH, Kim KI, Chin HJ, et al. U-shape relationship of white blood cells with acute kidney injury and mortality in critically ill patients. Tohoku J Exp Med. 2014;232(3):177-85.

64. Kim JH, Park YS, Yoon CY, Lee HS, Kim S, Lee JW, et al. Delta neutrophil index for the prediction of the development of sepsis-induced acute kidney injury in the emergency department. Shock. 2019;1:1. https://doi. org/10.1097/SHK.0000000000001299 (Epub ahead of print).

65. Kim WH, Park JY, Ok SH, Shin IW, Sohn JT. Association between the neutrophil/lymphocyte ratio and acute kidney injury after cardiovascular surgery: a retrospective observational study. Medicine (Baltimore). 2015;94(43):e1867.

66. Parlar H, Saşkın H. Are pre and postoperative platelet to lymphocyte ratio and neutrophil to lymphocyte ratio associated with early postoperative AKI following CABG? Braz J Cardiovasc Surg. 2018;33(3):233-41.

67. Kim HY, Kong YG, Park JH, Kim YK. Acute kidney injury after burn surgery: preoperative neutrophil/lymphocyte ratio as a predictive factor. Acta Anaesthesiol Scand. 2019:63(2):240-7.

68. Yuan Y, Qiu H, Hu X, Luo T, Gao X, Zhao X, et al. Predictive value of inflammatory factors on contrast-induced acute kidney injury in patients who underwent an emergency percutaneous coronary intervention. Clin Cardiol. 2017:40(9):719-25.

69. Yilmaz H, Cakmak M, Inan O, Darcin T, Akcay A. Can neutrophil-lymphocyte ratio be independent risk factor for predicting acute kidney injury in patients with severe sepsis? Ren Fail. 2015;37(2):225-9. 
70. Bu X, Zhang L, Chen P, Wu X. Relation of neutrophil-to-lymphocyte ratio to acute kidney injury in patients with sepsis and septic shock: a retrospective study. Int Immunopharmacol. 2019;70:372-7.

71. Doi K, Rabb H. Impact of acute kidney injury on distant organ function: recent findings and potential therapeutic targets. Kidney Int. 2016;89(3):555-64.

72. Abu Alfeilat M, Slotki I, Shavit L. Single emergency room measurement of neutrophil/lymphocyte ratio for early detection of acute kidney injury (AKI). Intern Emerg Med. 2018;13(5):717-25.

73. Gameiro J, Agapito Fonseca J, Monteiro Dias J, Melo MJ, Jorge S, Velosa J, et al. Prediction of acute kidney injury in cirrhotic patients: a new score combining renal, liver and inflammatory markers. Int J Nephrol Renovasc Dis. 2018;11:149-54.

74. Younan D, Richman J, Zaky A, Pittet JF. An increasing neutrophil-to-lymphocyte ratio trajectory predicts organ failure in critically-ill male trauma patients. An exploratory study. Healthcare (Basel). 2019;7(1):E42.

75. Fan LL, Wang YJ, Nan CJ, Chen YH, Su HX. Neutrophil-lymphocyte ratio is associated with all-cause mortality among critically ill patients with acute kidney injury. Clin Chim Acta. 2019;490:207-13.

76. Han JS, Park KS, Lee MJ, Kim CH, Koo HM, Doh FM, et al. Mean platelet volume is a prognostic factor in patients with acute kidney injury requiring continuous renal replacement therapy. J Crit Care. 2014;29(6):1016-21.

77. Tajarernmuang P, Phrommintikul A, Limsukon A, Pothirat C, Chittawatanarat K. The role of mean platelet volume as a predictor of mortality in critically ill patients: a systematic review and meta-analysis. Crit Care Res Pract. 2016;2016:4370834

78. Li J, Li Y, Sheng X, Wang F, Cheng D, Jian G, et al. Combination of mean platelet volume/platelet count ratio and the APACHE II score better predicts the short-term outcome in patients with acute kidney injury receiving continuous renal replacement therapy. Kidney Blood Press Res. 2018:43(2):479-89.

79. Zarychanski R, Houston DS. Assessing thrombocytopenia in the intensive care unit: the past, present, and future. Hematol Am Soc Hematol Educ Prog. 2017;2017(1):660-6.

80. Vanderschueren S, De Weerdt A, Malbrain M, Vankersschaever D, Frans E, Wilmer A, et al. Thrombocytopenia and prognosis in intensive care. Crit Care Med. 2000;28(6):1871-6.

81. Van Linden A, Kempfert J, Rastan AJ, Holzhey D, Blumenstein J, Schuler $\mathrm{G}$, et al. Risk of acute kidney injury after minimally invasive transapical aortic valve implantation in 270 patients. Eur J Cardiothorac Surg. 2011;39(6):835-42 (discussion 842-3)
82. Kertai MD, Zhou S, Karhausen JA, Cooter M, Jooste E, Li YJ, et al. Platelet counts, acute kidney injury, and mortality after coronary artery bypass grafting surgery. Anesthesiology. 2016;124(2):339-52.

83. Fan H, Zhao Y, Zhu JH, Song FC, Ye JH, Wang ZY, et al. Thrombocytopenia as a predictor of severe acute kidney injury in patients with heat stroke. Ren Fail. 2015;37(5):877-81.

84. Chao CT, Tsai HB, Chiang CK, Huang JW, COGENT study group. Thrombocytopenia on the first day of emergency department visit predicts higher risk of acute kidney injury among elderly patients. Scand J Trauma Resusc Emerg Med. 2017;25(1):11.

85. Wu M, Luan YY, Lu JF, Li H, Zhan HC, Chen YH, et al. Platelet count as a new biomarker for acute kidney injury induced by hemorrhagic shock. Platelets. 2019;27:1-9.

86. Koo CH, Eun Jung D, Park YS, Bae J, Cho YJ, Kim WH, et al. Neutrophil, lymphocyte, and platelet counts and acute kidney injury after cardiovascular surgery. J Cardiothorac Vasc Anesth. 2018;32(1):212-22.

87. Gameiro J, Fonseca JA, Dias JM, Milho J, Rosa R, Jorge S, et al. Neutrophil, lymphocyte and platelet ratio as a predictor of postoperative acute kidney injury in major abdominal surgery. BMC Nephrol. 2018;19(1):320.

88. Azab B, Shah N, Akerman M, Mcginn JT. Value of platelet/lymphocyte ratio as a predictor of all-cause mortality after non-ST-elevation myocardial infarction. J Thromb Thromb. 2012;34(3):326-34.

89. Hudzik B, Szkodziński J, Korzonek-Szlacheta I, Wilczek K, Gierlotka M, Lekston A, et al. Platelet-to-lymphocyte ratio predicts contrast-induced acute kidney injury in diabetic patients with ST-elevation myocardial infarction. Biomark Med. 2017;11(10):847-56.

90. Sun XP, Li J, Zhu WW, Li DB, Chen H, Li HW, et al. Platelet to lymphocyte ratio predicts contrast-induced nephropathy in patients with ST-segment elevation myocardial infarction undergoing primary percutaneous coronary intervention. Angiology. 2018;69(1):71-8.

91. Zheng CF, Liu WY, Zeng FF, Zheng MH, Shi HY, Zhou Y, et al. Prognostic value of platelet-to-lymphocyte ratios among critically ill patients with acute kidney injury. Crit Care. 2017;21(1):238

\section{Publisher's Note}

Springer Nature remains neutral with regard to jurisdictional claims in published maps and institutional affiliations.

\section{Submit your manuscript to a SpringerOpen ${ }^{\circ}$ journal and benefit from:}

- Convenient online submission

- Rigorous peer review

- Open access: articles freely available online

- High visibility within the field

- Retaining the copyright to your article

Submit your next manuscript at springeropen.com 